University of Nebraska - Lincoln

DigitalCommons@University of Nebraska - Lincoln

2006

\title{
Distribution of boreal toad populations in relation to estimated UV-B dose in Glacier National Park, Montana, USA
}

Blake R. Hossack

Aldo Leopold Wilderness Research Institute, blake_hossack@usgs.gov

Stephen A. Diamond

US Environmental Protection Agency

Paul Stephen Corn

Aldo Leopold Wilderness Research Institute

Follow this and additional works at: https://digitalcommons.unl.edu/usgsstaffpub

Part of the Earth Sciences Commons

Hossack, Blake R.; Diamond, Stephen A.; and Corn, Paul Stephen, "Distribution of boreal toad populations in relation to estimated UV-B dose in Glacier National Park, Montana, USA" (2006). USGS Staff -- Published Research. 95.

https://digitalcommons.unl.edu/usgsstaffpub/95

This Article is brought to you for free and open access by the US Geological Survey at DigitalCommons@University of Nebraska - Lincoln. It has been accepted for inclusion in USGS Staff -- Published Research by an authorized administrator of DigitalCommons@University of Nebraska - Lincoln. 


\title{
Distribution of boreal toad populations in relation to estimated UV-B dose in Glacier National Park, Montana, USA
}

\author{
Blake R. Hossack, Stephen A. Diamond, and Paul Stephen Corn
}

\begin{abstract}
A recent increase in ultraviolet B radiation is one hypothesis advanced to explain suspected or documented declines of the boreal toad (Bufo boreas Baird and Girard, 1852) across much of the western USA, where some experiments have shown ambient UV-B can reduce embryo survival. We examined $B$. boreas occupancy relative to daily UV-B dose at 172 potential breeding sites in Glacier National Park, Montana, to assess whether UV-B limits the distribution of toads. Dose estimates were based on ground-level UV-B data and the effects of elevation, local topographic and vegetative features, and attenuation in the water column. We also examined temporal trends in surface UV-B and spring snowpack to determine whether populations are likely to have experienced increased UV-B exposure in recent decades. We found no support for the hypothesis that UV-B limits the distribution of populations in the park, even when we analyzed high-elevation ponds separately. Instead, toads were more likely to breed in water bodies with higher estimated UV-B doses. The lack of a detectable trend in surface UV-B since 1979, combined with earlier snow melt in the region and increasing forest density at high elevations, suggests $B$. boreas embryos and larvae likely have not experienced increased UV-B.
\end{abstract}

Résumé : L'augmentation récente de le rayonnement ultraviolet $\mathrm{B}$ est l'une des hypothèses avancées pour expliquer les déclins appréhendés ou observés du crapaud de l'ouest (Bufo boreas Baird et Girard, 1852) dans presque tout l'ouest des É.-U.; certaines expériences y ont d'ailleurs démontré que l'UV-B ambiant peut réduire la survie des embryons. Nous avons déterminé l'occupation du territoire par $B$. boreas en fonction des doses journalières d'UV-B à 172 sites potentiels de reproduction dans le parc national Glacier, Montana, afin d'évaluer si l'UV-B limite la répartition des crapauds. Les estimations du dosage ont été basées sur des mesures d'UV-B au niveau du sol et sur les effets de l'altitude, de la topographie locale, des caractéristiques de la végétation et de l'atténuation dans la colonne d'eau. Nous avons aussi examiné les variations temporelles de l'UV-B en surface, ainsi que la couche de neige au printemps afin de savoir si les populations ont pu être soumises à des expositions accrues au cours des dernières décennies. Nous n'avons rien trouvé qui appuie l'hypothèse selon laquelle l'UV-B limite la répartition de la population dans le parc, même lorsque nous analysons les données sur les étangs de haute altitude séparément. Au contraire, les crapauds sont plus susceptibles de se reproduire dans les masses d'eau qui reçoivent les doses estimées d'UV-B les plus fortes. L'absence de tendance décelable de l'UV-B en surface depuis 1979, combinée à une fonte des neiges plus précoce dans la région et une densité accrue des forêts en haute altitude, laisse croire que les embryons et les larves de $B$. boreas n'ont vraisemblablement pas été exposés à une augmentation de l'UV-B.

[Traduit par la Rédaction]

\section{Introduction}

The western toad complex (Bufo boreas Baird and Girard, 1852 and sibling species) is distributed over much of North America west from the Rocky Mountains, and declines have been documented (Kagarise Sherman and Morton 1993; Fisher and Shaffer 1996; Muths et al. 2003) or are suspected

Received 15 August 2005. Accepted 13 December 2005.

Published on the NRC Research Press Web site at http://cjz.nrc.ca on 11 February 2006.

B.R. Hossack ${ }^{1}$ and P.S. Corn. US Geological Survey, Aldo Leopold Wilderness Research Institute, 790 East Beckwith Avenue, Missoula, MT 59801, USA.

S.A. Diamond. US Environmental Protection Agency, MidContinent Ecology Division, 6201 Congdon Boulevard, Duluth, MN 55804, USA.

${ }^{1}$ Corresponding author (e-mail: blake_hossack@usgs.gov).
(Blaustein et al. 1994; Adams et al. 1998; Maxell et al. 2003) throughout much of the southern half of its range. Blaustein et al. (1994) reported that boreal toad (Bufo boreas) embryos exposed to ambient sunlight had lower hatching success than embryos that were shielded from ultraviolet B radiation (UV-B, 280-320 nm). A subsequent experiment demonstrated a synergistic relationship between UV-B and the water mold Saprolegnia ferax Kütz. that caused mortality of embryos (Kiesecker and Blaustein 1995). Results from these studies and increases in UV-B due to ozone depletion (Kerr and McElroy 1993; Herman et al. 1996) led to the hypothesis that increasing UV-B may have caused declines of $B$. boreas (Blaustein et al. 1998).

Recent research suggests amphibians in most aquatic habitats are protected from UV-B by high concentrations of colored dissolved organic carbon (DOC) (Adams et al. 2001; Diamond et al. 2002; Palen et al. 2002; Adams et al. 2005). Terrestrially derived DOC is highly effective at absorbing 
and attenuating UV-B, making UV-B flux decrease rapidly with depth (Scully and Lean 1994; Schindler and Curtis 1997). Several physiological mechanisms also protect embryos from UV-B exposure; combined with oviposition behaviour, these mechanisms may make the high levels of mortality observed in some experiments an unusual occurrence for most species (Licht 2003; Palen et al. 2005). However, some amphibian species in western North America, including $B$. boreas, commonly breed in shallow, low-DOC water bodies (Vredenburg 2002; Adams et al. 2005) and thus may be vulnerable to ambient UV-B.

Adams et al. (2005) examined the distributions of eight amphibian species in relation to estimated maximum daily UV-B dose in three montane national parks in the western United States: Glacier, Olympic, and Sequoia \& Kings Canyon. Bufo boreas was too rare in that study for its distribution in relation to UV-B to be formally assessed. Bufo boreas is more common in Glacier National Park (hereafter, GLAC) than in most other areas of western Montana, yet breeding occurs at only approximately $10 \%$ of sites surveyed in the park each year (Corn et al. 2005). Several factors suggest that populations of this species could be affected by UV-B. Eggs are often laid in water $<10 \mathrm{~cm}$ deep, frequently in habitats with little or no emergent aquatic vegetation (Corn 1998; Hammerson 1999), and larvae typically form large aggregations in the shallowest waters to maximize their body temperature (O'Hara and Blaustein 1982). Also, most populations of $B$. boreas in GLAC are small, probably composed of five or fewer breeding pairs per year. These risk factors led us to further assess the hypothesis that UV-B is limiting the distribution of toads in GLAC.

Subsequent to the fieldwork reported in Adams et al. (2005), our continuing surveys documented additional B. boreas breeding sites in GLAC (Corn et al. 2005). Estimation of ground-based UV-B doses for these new sites allowed us to better assess whether or not UV-B influences the distribution of populations. We used estimated 1-day UV-B doses for ponds along with elevation, estimated solar dose, and habitat data to evaluate the relationship between UV-B and the distribution of $B$. boreas breeding sites across the park. We also conducted a separate exploratory analysis of high-elevation water bodies $(\geq 1800 \mathrm{~m})$. Toads at high elevations breed closer to the summer solstice in ponds with little vegetation, so their embryos may receive greater doses of UV-B. If UV-B is a limiting factor for B. boreas in GLAC, we would expect habitats with higher estimated UV-B doses to be less likely to be occupied by breeding populations. We also examined temporal trends in surface UV-B exposure using erythemal dose estimates from satellites and timing of spring snow melt to determine whether or not $B$. boreas populations are likely to have been exposed to increasing doses of UV-B.

\section{Materials and methods}

\section{Study area}

Glacier National Park is a reserve of 410360 ha situated along the Continental Divide in northwestern Montana. Much of the park is characterized by U-shaped valleys that reflect the extensive glaciation of the region during the Pleistocene.
West of the Continental Divide, the park is dominated by a moist Pacific maritime climate. The climate east of the Divide is colder and drier because of the influence of continental-polar air masses (Carrara 1989). The Flattop Mountain Snowpack Telemetry (SNOTEL) site, centrally located in the park just west of the Continental Divide at $1922 \mathrm{~m}$ elevation, averages $119 \mathrm{~cm}$ of snow water equivalent and $175 \mathrm{~cm}$ of precipitation annually (Natural Resources Conservation Service 2005). A variety of habitats are present as a result of the topographic and climatic variation in the park, ranging from western redcedar (Thuja plicata Donn ex D. Don) - western hemlock (Tsuga heterophylla (Raf.) Sarg.) forests typical of the Pacific Northwest to alpine tundra and grasslands. Water bodies (hereafter, ponds) surveyed for this study ranged from vernal pools in dense forest to small glacial lakes $>10$ ha in size.

\section{Amphibian surveys}

Areas surveyed in 1999-2000 for the Adams et al. (2005) study were based on watershed boundaries and were chosen to encompass a broad range of environmental gradients present in the park. In each of the selected watersheds, all accessible lentic habitats were surveyed. Surveys continued in 2001 in randomly selected watersheds and resulted in the documentation of additional $B$. boreas breeding locations in areas not previously surveyed. During summer 2002, we resurveyed watersheds with toad breeding sites that were discovered in 2001 and collected information needed to estimate UV-B dose. All data we report are from 2000 or 2002. All ponds within the perimeter of the 2001 Moose Fire in GLAC were excluded because we were unsure of how the relationship between $B$. boreas and UV-B would be affected by recent fire.

We used visual encounter surveys to assess presence or non-detection of embryos and larvae. Surveys were timed to coincide with the period of approximately 6-8 weeks during which larvae were expected to be present, depending upon elevation and aspect. We searched the perimeter and shallow $(\leq 0.5 \mathrm{~m})$ areas of each wetland, using dip nets in areas with thick vegetation or where water clarity was poor. A pond was considered a breeding site only if embryos or tadpoles were detected during at least one survey in the year in which water samples were collected. Based on multiple surveys of the same sites in 1999-2002, the probability of detecting B. boreas larvae with a single survey exceeded $90 \%$.

\section{Habitat characterization}

For each pond, we quantified a range of biotic and abiotic habitat parameters. Dominant shoreline substrate was recorded as silt (particle size $<0.5 \mathrm{~mm}$ in diameter), sand (0.5$2 \mathrm{~mm}$ ), gravel $(>2-75 \mathrm{~mm})$, cobble $(>75-300 \mathrm{~mm})$, boulder $(>300 \mathrm{~mm})$, bedrock, wood, or leaf/grass litter. We visually estimated the maximum depth $(\leq 1 \mathrm{~m},>1 \mathrm{~m})$ of each pond and the percentage of the pond with emergent vegetation. Elevation was estimated from USGS $7.5^{\prime}$ topographical maps.

\section{UV-B dose estimates in ponds}

We estimated the maximum daily UV-B dose that a tadpole or egg mass $1 \mathrm{~cm}$ beneath the water's surface would experience, accounting for elevation, topography, shading 
vegetation, surface reflection, and attenuation by DOC. The methods are described briefly here; details are available in Diamond et al. (2005). Estimates of UV-B dose were based on ground-level, hourly solar radiation data (spectroradiometric scans from 290 to $365 \mathrm{~nm}$ ) collected by Brewer spectrometers during 1997-2001 at a single location in GLAC (see http://www.epa.gov/uvnet/). These data were analyzed to determine the highest 95th percentile of daily UV-B doses for each year, which were then averaged over all years. This value is an estimate of the maximum (clear-sky) summersolstice UV-B dose at the Brewer instrument location. We estimated the total solar radiation dose at all visited ponds and at the Brewer instrument location on the summer solstice using Solar Analyst (Helios Environmental Modeling Institute, Lawrence, Kansas), a GIS-based solar radiation model that incorporates the effect of landscape features on solar radiation dose by accounting for both direct shading effects and occlusion of portions of the sky from which diffuse solar radiation is emitted (Rich et al. 1995). The model estimates total solar radiation from 300 to $3000 \mathrm{~nm}$. The final solar radiation dose estimated for each pond was divided by the dose estimated for the park's Brewer instrument location to derive a proportionality factor that represented the relative effect of landscape for each pond location. A second solar radiation model, SBDART (Santa Barbara DISORT (Discrete Ordinate Radiative Transfer) Atmospheric Radiative Transfer; Ricchiazzi et al. 1998; Institute for Computational Earth System Science 2006), was used to generate a solar irradiance spectrum (irradiance per nanometre) for wavelengths from 280 to $700 \mathrm{~nm}$, representing the average spectral irradiance on the summer solstice at the surface of each pond. The spectra were reduced by $6.5 \%$ to account for surface reflection (Jerlov 1976; Green and Shippnick 1982; Jerome and Bukata 1998). Water-column attenuation was incorporated by multiplying the spectrum for each pond by the proportionate transmittance derived from laboratory scans (1 cm path length) of filtered water samples collected during amphibian surveys. Water samples $(60 \mathrm{~mL})$ were filtered in the field using $0.7 \mu \mathrm{m}$ ashed glass fiber filters and kept cool until analysis (ca. 1 week). The final solar spectrum for each pond was an estimate of the average intensity of solar radiation on the summer solstice at a depth of $1 \mathrm{~cm}$ in the pond.

For each pond, UV-B dose was calculated by integrating the pond's irradiance spectrum from 280 to $320 \mathrm{~nm}$ and multiplying the result by day length on the summer solstice at the pond's location. The resulting values are estimates of the maximal (cloud-free conditions) summer-solstice UV-B dose at $1 \mathrm{~cm}$ depth in each pond. The models used incorporate average atmospheric conditions that include appropriate values for ozone, particulates, aerosols, water vapor, and other factors. Vegetative features were assumed to have shading effects similar to those of topographic features that would occlude portions of the sky. No effort was made to adjust these values for typical weather conditions, as little or no climatological data are available for specific pond locations. However, it is reasonable to assume that average weather conditions would not greatly alter the relative UV-B dose among ponds and that our UV-B estimates provide a reasonable basis for comparing relative UV-B exposure and amphibian distributions.

The uncertainty of the UV-B dose estimates presented here is difficult to evaluate quantitatively. While the Brewer spectrometer data provide excellent ground-level information and are invaluable as a starting point for these calculations, there are no wetland UV dose values available that are suitable for direct comparison. Where UV-B has been measured in wetlands, the comparability of the data is limited by the use of less accurate broadband instruments and by limited information on the effect of landscape and the atmospheric conditions during measurements, and the measurements are generally UV-B flux rather than dose estimates. The validity of the modeled effect of landscape was evaluated using Brewer spectrometer data for six national parks (Acadia, Maine; Great Smoky Mountains, Tennessee and North Carolina; Olympic, Washington; Rocky Mountain, Colorado; Sequoia \& Kings Canyon, California; and GLAC; Diamond et al. 2005). UV-B dose estimates were made for Brewer spectrometer locations with and without landscape features being taken into account; inclusion of a landscape effect reduced the error from $33 \%$ to $9 \%$ in GLAC. In Olympic and Sequioa \& Kings Canyon national parks, the error was reduced from $27 \%$ and $21 \%$, respectively, to approximately $4 \%$. While this exercise is not a thorough model validation, it does indicate that the magnitude of adjustment for a landscape effect is reasonable. The uncertainties in these estimates are discussed further by Diamond et al. (2005).

\section{Temporal trend in erythemal UV-B}

Fundamental to the hypothesis that recent increases in UV-B may cause amphibian decline is the assumption that amphibians are receiving increased doses of UV-B. To evaluate potential recent increases in estimated surface UV-B, we obtained data on erythemal exposure (UV-B weighted by the action spectrum for human skin irritation) from the Nimbus7 (1979-1992) and Earth Probe (1997-2003) satellites (National Aeronautics and Space Administration 2005). No data are available before 1979 or for 1993-1996 because of satellite failure. The Total Ozone Mapping Spectrometer (TOMS) data provide global estimates of daily erythemal exposure $\left(\mathrm{J} \cdot \mathrm{m}^{-2}\right)$, adjusted for average elevation, on a grid $1^{\circ}$ latitude by $1.25^{\circ}$ longitude.

We used data from the grid cell centered at $48.5^{\circ} \mathrm{N}$, $114.375^{\circ} \mathrm{W}$, which does not encompass all of GLAC but includes the center of the park and most documented $B$. boreas breeding sites. The average exposure was calculated for the dates of 1 May to 30 June, the time period during which most populations breed. Averaging data over $\geq 7$ days also increases the concordance between satellite and ground estimates of surface UV-B (Herman et al. 1996, 1999). TOMS values are conservative estimates of UV-B exposure in mountainous areas and cannot be used to predict the UV-B dose at any given location, but the data are useful for showing regional trends (Middleton et al. 2001).

\section{Temporal trend in snowpack}

Breeding phenology can affect UV-B exposure (Corn and Muths 2002; Cummins 2003), and the timing of breeding of montane amphibians can be predicted from the amount of snow accumulated over winter (Corn and Muths 2002; Corn 2003). Snow accumulation data (measured as snow water equivalent, SWE) for 1 June 1961-2003 were obtained for 
the Flattop Mountain snow course (Natural Resources Conservation Service 2005). We used 1 June because it was the latest calendar date for which measurements are available for each year of record, and it precedes the timing of breeding of most toad populations in GLAC.

\section{Analysis}

Because $B$. boreas can be absent from entire watersheds for unknown reasons, our analyses include only watersheds with at least one documented breeding site. We fit competing logistic regression models of the presence or nondetection of $B$. boreas, with estimated daily UV-B dose, Elevation, SolarDose, and PondType as predictor variables. SolarDose is an estimate of the solar energy received by each pond on the summer solstice after accounting for vegetative and geographic shading. The amount of sun received by a water body is related to maximum littoral water temperature (Steedman et al. 2001), which is an important determinant of which ponds are used for amphibian breeding (Banks and Beebee 1987). PondType is a synthetic variable that combines depth, substrate composition, and emergent vegetation (Adams et al. 2005; Table 1). Although UV-B is correlated with elevation (Blumthaler et al. 1992), only $15 \%$ of the variation in estimated daily maximum UV-B dose was attributable to elevation after accounting for DOC (Fig. 1). Similarly, SolarDose explained only $1 \%$ of the variation in UV-B dose after accounting for DOC concentration, because dissolved organic matter is the primary controller of UV-B in the water column.

We included Elevation, SolarDose, and PondType (collectively termed "Habitat") in all candidate models and evaluated the effect of adding UV-B terms because our goal was to assess the relationship between estimated UV-B dose and the distribution of breeding sites, not the importance of specific habitat features. We fit the following models: Habitat, Habitat + UV-B, Habitat + UV-B ${ }^{2}$, Habitat + (UV-B $\times$ Elevation), Habitat + (UV-B $\times$ SolarDose), and Habitat $+(\mathrm{UV}-\mathrm{B} \times$ PondType). The quadratic term was added to account for the possibility that negative effects of UV-B may be seen only at high doses. Interaction terms were included because the effect of UV-B may not be constant across the range of data sampled or in all types of wetlands.

Models were ranked according to differences in the second-order Akaike's information criterion adjusted for small sample size $\left(\mathrm{AIC}_{\mathrm{c}}\right)$ and model weights $\left(w_{i}\right)$ (Burnham and Anderson 2002). Model weights represent the probability that a model is the best of those being considered for the data set (Burnham and Anderson 2002). Analyses were conducted using the generalized linear model procedure in SPLUS 2000 (MathSoft Engineering and Education, Inc., Cambridge, Massachusetts).

\section{Results}

Estimated mean daily UV-B dose at $1 \mathrm{~cm}$ depth on the summer solstice averaged $20.84 \mathrm{~W} \cdot \mathrm{h} \cdot \mathrm{m}^{-2}$ (range $=7.40-$ $25.75 \mathrm{~W} \cdot \mathrm{h} \cdot \mathrm{m}^{-2}$ ) for the 172 ponds sampled in the nine watersheds with a documented breeding site. Approximately $60 \%$ of the variation in estimated UV-B dose was a result of differences in DOC. Restricting the analysis to the watersheds that contained $B$. boreas breeding sites did not result in
Table 1. Description of pond categories (PondTypes) created by grouping common habitat characteristics; some habitat characteristics did not co-occur.

\begin{tabular}{ll}
\hline Pond characteristics & No. of ponds \\
\hline Shallow, coarse substrate, low cover & 18 \\
Shallow, fine substrate, low cover & 40 \\
Shallow, fine substrate, high cover & 54 \\
Deep, coarse substrate, low cover & 23 \\
Deep, fine substrate, low cover & 17 \\
Deep, fine substrate, high cover & 20 \\
\hline
\end{tabular}

Note: Depth: shallow $=\leq 1 \mathrm{~m}$, deep $=>1 \mathrm{~m}$. Substrate: coarse = gravel, cobble, boulder, bedrock; fine = silt/mud, sand, leaf/grass litter. Cover: low $=\leq 25 \%$, high $=>25 \%$.

a bias away from high-UV environments. To the contrary, ponds in watersheds where $B$. boreas was not detected had lower estimated UV-B doses, on average $(n=215, \bar{x}=$ $\left.17.45 \mathrm{~W} \cdot \mathrm{h} \cdot \mathrm{m}^{-2}, s=5.91\right)$, than ponds in watersheds with breeding populations $\left(n=172, \bar{x}=20.84 \mathrm{~W} \cdot \mathrm{h} \cdot \mathrm{m}^{-2}, s=\right.$ 4.20). In watersheds containing breeding sites, the association of $B$. boreas with UV-B was weakly positive (Fig. 2). Average UV-B dose at the 37 breeding sites $\left(\bar{x}=21.95 \mathrm{~W} \cdot \mathrm{h} \cdot \mathrm{m}^{-2}\right.$, range $=8.59-25.65 \mathrm{~W} \cdot \mathrm{h} \cdot \mathrm{m}^{-2}$ ) was higher than that at the 135 non-breeding sites $\left(\bar{x}=20.53 \mathrm{~W} \cdot \mathrm{h} \cdot \mathrm{m}^{-2}\right.$, range $=7.40-25.75$ $\mathrm{W} \cdot \mathrm{h} \cdot \mathrm{m}^{-2}$ ). There was no linear trend in log-transformed surface UV-B for the 1 May - 30 June period in the western portion of GLAC during 1979-2003 (slope $=0.001,95 \% \mathrm{CL}=$ $-0.002,0.003$; Fig. 3), nor in log-transformed SWE on Flattop Mountain on 1 June between 1961 and 2003 (slope = $-0.001,95 \% \mathrm{CL}=-0.006,0.003$; Fig. 4).

The simplest logistic regression model, with only Habitat as a predictor, received the most support (Table 2). The model that included the UV-B $\times$ SolarDose interaction explained the most variation in the data and received the second most support (Table 2). The odds of detecting $B$. boreas increased with UV-B but the slope varied with SolarDose. The Habitat + UV-B model, which indicated that the proportion of ponds occupied increased slightly with UV-B, had the third largest model weight but did not explain any additional deviance (Table 2). The difference in $\mathrm{AIC}_{\mathrm{c}}$ between the most likely and the third most likely model was due solely to the addition of the UV-B term, which means there is no support for adding it (Burnham and Anderson 2002). The remaining models all had weights of $\leq 0.06$ and explained little variation in addition to that explained by the basic habitat model.

We explored the UV-B $\times$ SolarDose interaction further by removing ponds at $<1800 \mathrm{~m}$ elevation from the analysis because plots of the data showed that the relationship between UV-B and sun exposure was different at high elevations. This limited the data set to 70 ponds between $1800 \mathrm{~m}$ and $2181 \mathrm{~m}$ elevation, including 26 breeding sites. Dissolved organic carbon was not strongly related to UV-B $\left(r_{\mathrm{S}}=-0.33\right)$ in this group of ponds, so it was used as a predictor variable. We compared eight logistic regression models (Table 2) using the same methods as above except Elevation was not used as a predictor variable and interactions and quadratic terms were not considered with such a narrow range of data. The PondType + DOC model received the most support, fol- 
Fig. 1. Relationship between estimated daily UV-B dose at $1 \mathrm{~cm}$ depth and elevation for 172 ponds in Glacier National Park. Triangles represent ponds where Bufo boreas larvae were found, and circles represent ponds where they were not found.

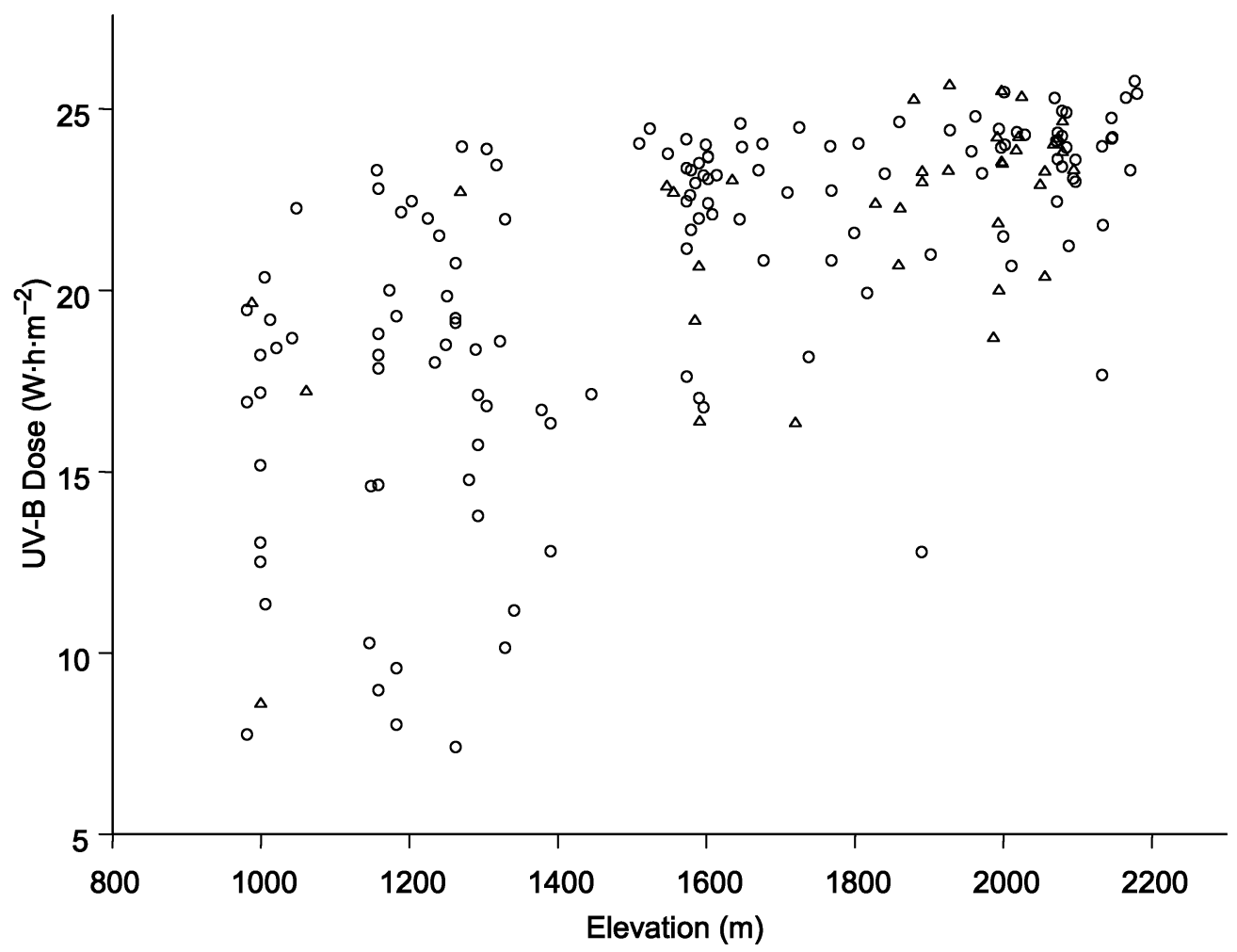

Fig. 2. Probability of occurrence of Bufo boreas larvae in relation to estimated daily UV-B dose in ponds in watersheds containing $\geq 1$ breeding site. Each circle represents one pond.

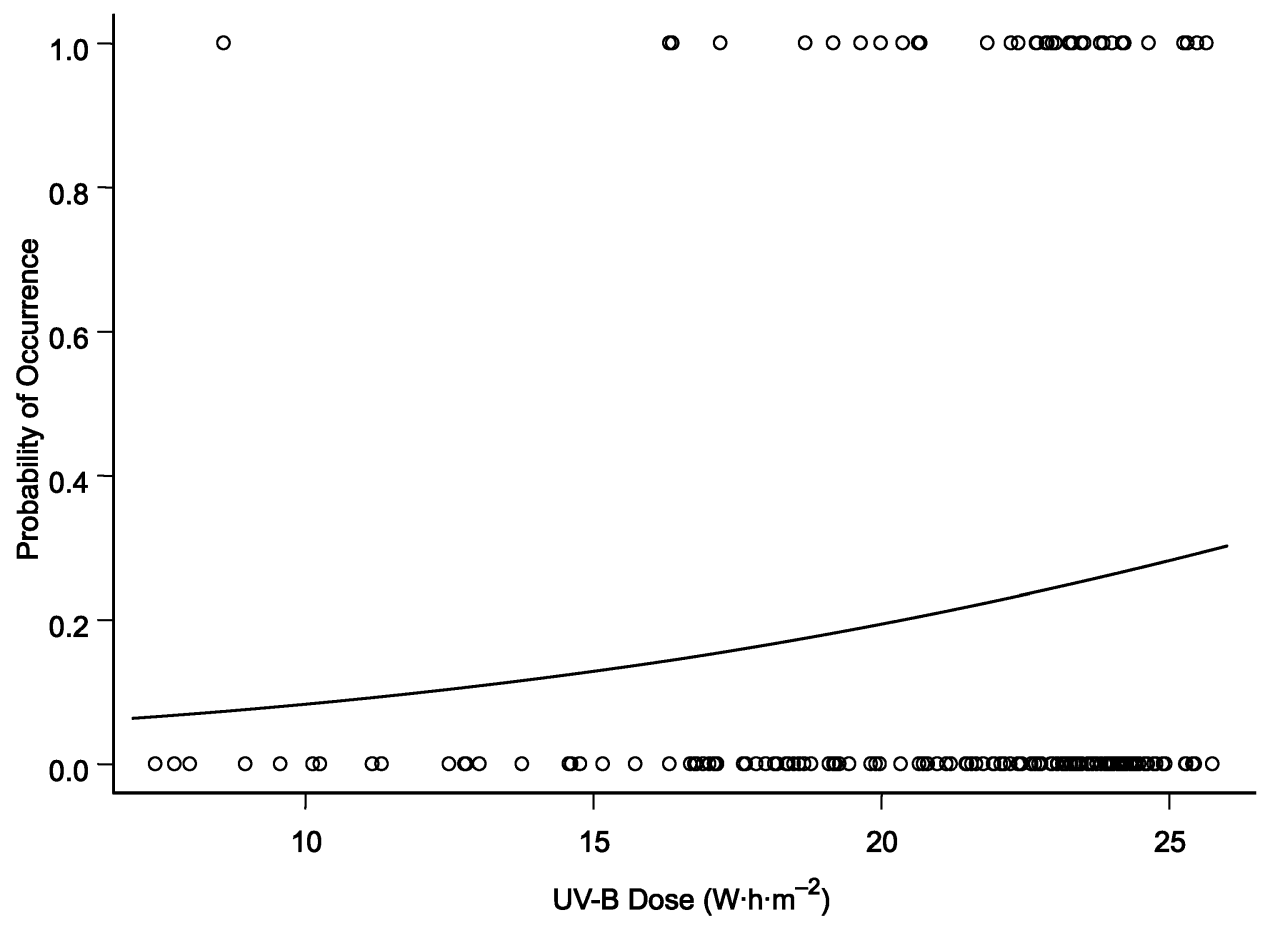

lowed closely by the PondType + DOC + UV-B model (Table 2). Four of the top five models included DOC as a predictor variable, indicating its relative importance in this data set. The DOC coefficient was positive in the four models in which it was included, as was the UV-B coefficient. 
Fig. 3. Mean 1 May - 30 June (1979-1992, 1997-2003; circles) and 3-year moving average (line) erythemal UV-B for the $1^{\circ}$ latitude by $1.25^{\circ}$ longitude cell that contains most of the Bufo boreas breeding sites in Glacier National Park. Data from 1993-1996 are missing because of satellite failure.

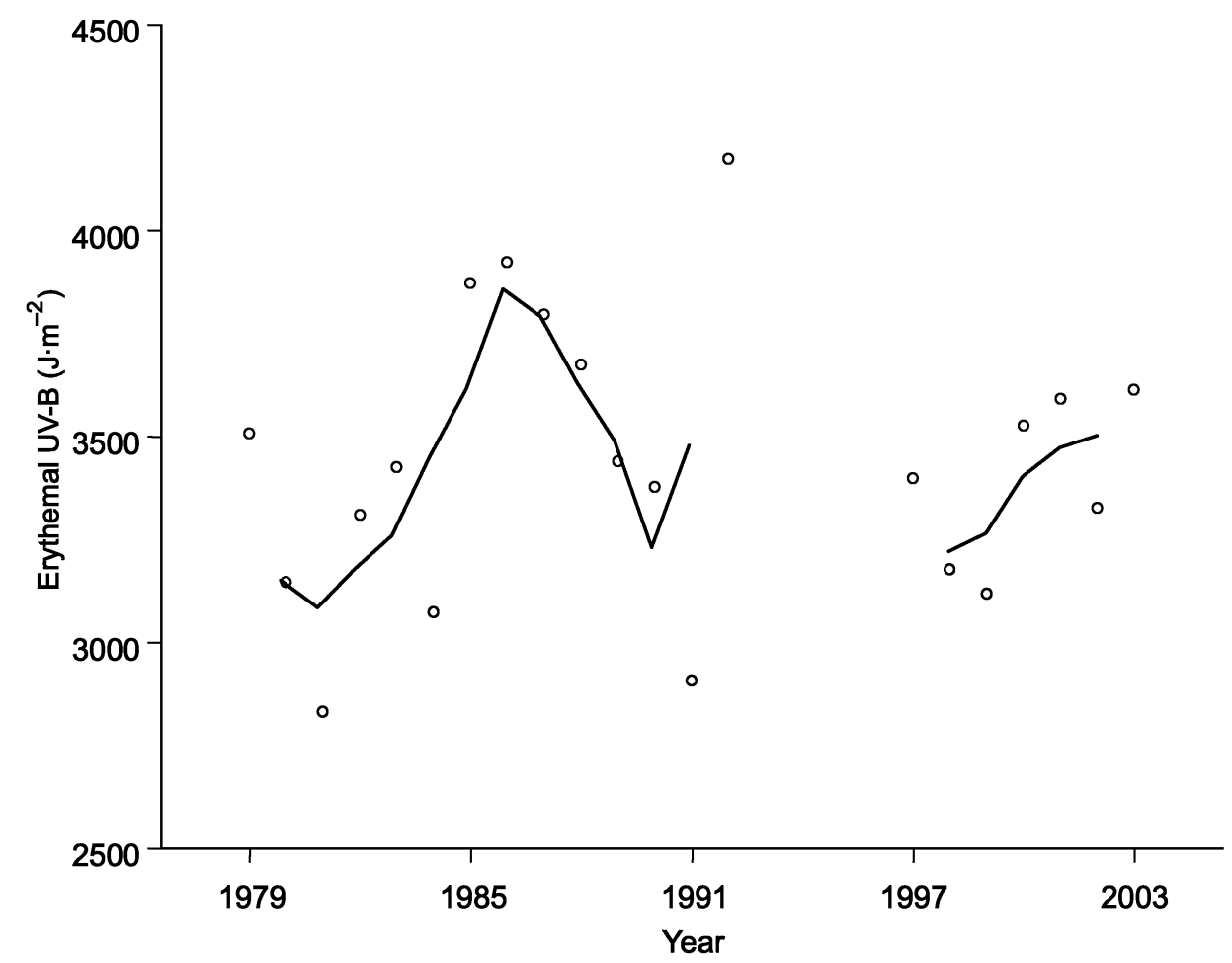

Fig. 4. Snow water equivalent on 1 June (circles) and the 5-year moving average (line) on Flattop Mountain, Montana, $1961-2003$.

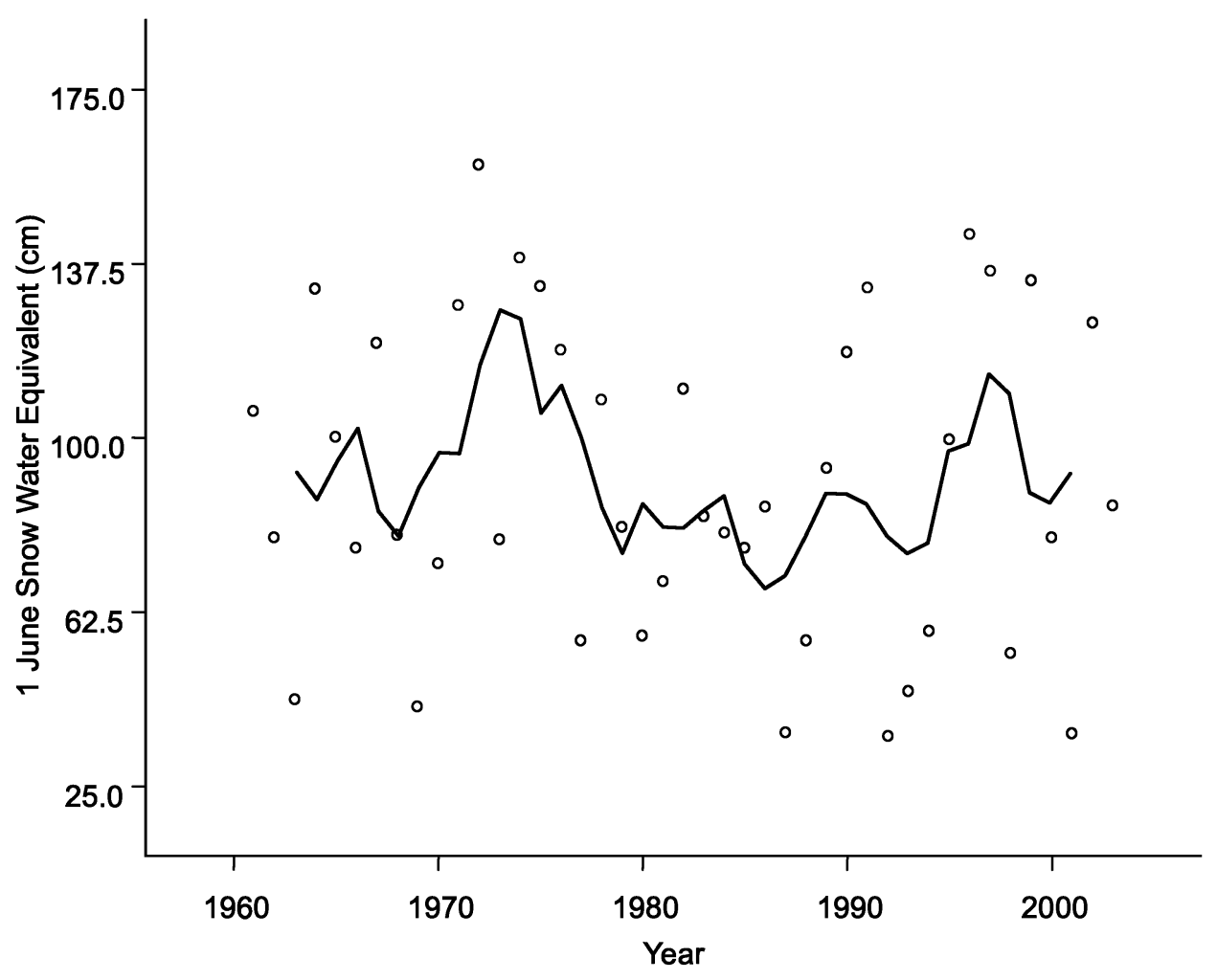

To evaluate consistency in DOC between years, water samples were collected from 18 ponds in 2002 that were also sampled in 2000. A large snowpack in 2002 caused most samples to be collected later in the summer in 2002 than in 2000, when the snowpack was below average. After accounting for differences in SWE on the collection dates, 
Table 2. Summary of logistic regression models used to relate the occurrence of Bufo boreas breeding populations to estimated daily UV-B dose for the entire data set and for ponds at $\geq 1800 \mathrm{~m}$ elevation.

\begin{tabular}{|c|c|c|c|c|}
\hline Model & $K$ & $\begin{array}{l}\text { Residual } \\
\text { deviance }\end{array}$ & $\Delta \mathrm{AIC}_{\mathrm{c}}$ & $w_{i}$ \\
\hline \multicolumn{5}{|l|}{ All ponds } \\
\hline PondType + Elevation + SolarDose & 8 & 154.52 & 0.00 & 0.51 \\
\hline PondType + Elevation + SolarDose + UV-B + (UV-B $\times$ SolarDose $)$ & 10 & 151.85 & 1.81 & 0.21 \\
\hline PondType + Elevation + SolarDose + UV-B & 9 & 154.52 & 2.20 & 0.17 \\
\hline PondType + Elevation + SolarDose + UV-B + UV-B ${ }^{2}$ & 10 & 154.46 & 4.38 & 0.06 \\
\hline \multicolumn{5}{|l|}{ Ponds at $\geq 1800 \mathrm{~m}$ elevation } \\
\hline PondType + DOC & 7 & 76.78 & 0.00 & 0.39 \\
\hline PondType + DOC + UV-B & 8 & 75.06 & 0.83 & 0.26 \\
\hline PondType + DOC + SolarDose & 8 & 76.68 & 2.45 & 0.12 \\
\hline PondType & 6 & 82.42 & 3.17 & 0.08 \\
\hline
\end{tabular}

DOC values for the same ponds in the 2 years were strongly correlated $\left(r_{\mathrm{adj}}^{2}=0.80\right)$.

\section{Discussion}

The distribution of $B$. boreas in GLAC does not conform to the pattern expected if UV-B is limiting populations. If populations were limited by UV-B, ponds with the highest UV-B doses would be less likely to be used for breeding. Instead, we found that the probability of occurrence of $B$. boreas increased slightly with UV-B. However, the relationship was weak and most models that included UV-B terms explained little variation in the data after first accounting for elevation, sun exposure, and habitat features.

Moderate support for the model that included a positive UV-B $\times$ SolarDose interaction term revealed that above $1800 \mathrm{~m}$ elevation there was no difference in UV-B dose between occupied and unoccupied ponds even though toads were more likely to breed in ponds with higher levels of DOC. Dissolved organic carbon was positively associated with SolarDose at high elevations, and the weak relationship between bulk DOC and UV-B in high-elevation ponds (compared with the full data set) likely indicates that a substantial portion of the DOC was derived from algal sources, because DOC derived from algae does not provide as much protection from UV-B as terrestrially derived DOC (McKnight et al. 1997; Brooks et al. 2005). Bulk DOC was also a poor predictor of UV-B transmission in high-elevation ponds in Sequoia \& Kings Canyon national parks because it was derived mostly from algae (Brooks et al. 2005; Diamond et al. 2005). If DOC is an index of algal productivity in the highelevation ponds we sampled, one hypothesis to explain its positive association with breeding sites is that $B$. boreas select more productive ponds. Larval growth rates and distribution of some amphibians in the eastern USA, including the American toad (Bufo americanus Holbrook, 1836), are related to increased food resources and higher water temper- atures in ponds that receive more incident light (Werner and Glennenmeier 1999; Skelly et al. 2002; Halverson et al. 2003).

Satellite-based estimates of surface UV-B showed no increase for the May-June breeding period since 1979. Snowpack data for Flattop Mountain also showed no consistent pattern since 1961. Regionally, however, there is a trend toward earlier snow melt since 1950 (Selkowitz et al. 2002). Breeding phenology of amphibians in mountainous areas is controlled largely by timing of snow melt (Corn and Muths 2002; Corn 2003); therefore, a recent trend toward earlier breeding by $B$. boreas in the region is likely. Because UV-B flux is lower earlier in the year (Merilä et al. 2000; Corn and Muths 2002), most toad populations in GLAC probably have not been exposed to increased UV-B in recent decades. Further, increasing tree density at high elevations through the 20th century (Butler and DeChano 2001; Klasner and Fagre 2002) may have provided a greater pool of photo-protective DOC (e.g., Williamson et al. 2001). The situation of $B$. boreas may resemble that of the natterjack toad (Bufo calamita Laurenti, 1768) in the United Kingdom, where earlier breeding has led to a decrease in estimated UV-B exposure (Merilä et al. 2000; Cummins 2003). Similarly, Corn and Muths (2002) found that despite a large increase in surface UV-B in northern Colorado (26.7\% between 1979 and 2001) around the average date of breeding by the boreal chorus frog (Pseudacris maculata (Agassiz, 1850)) during 1986-2001, earlier breeding in years with low snowpack resulted in no temporal trend in surface UV-B to which $P$. maculata may have been exposed. Snowpack in the GLAC region varies considerably (27\% interannual variation between 1950 and 2001; Selkowitz et al. 2002) and is linked to decadal and longer-term climate cycles (Pederson et al. 2006). Variations in climate, timing of breeding, and weather during larval development likely interact to produce a wide range of UV-B exposures among populations and among years in GLAC and other mountainous areas. 
Observational studies such as ours cannot establish cause and effect, but they are a complementary method for determining whether patterns predicted from experiments are found at broader spatial scales. Our study is the second to examine the distribution of $B$. boreas breeding sites and UV$B$ across a network of water bodies (Palen et al. 2002), and both studies have failed to find a negative association. We did not find a relationship between UV-B and the distribution of $B$. boreas breeding sites even when we limited our analysis to high-elevation ponds, where any negative effects of UV-B are expected to be more apparent. Ambient UV-B in the presence of $S$. ferax can cause mortality of early life stages at some Oregon sites (Blaustein et al. 1994; Kiesecker et al. 2001); however, experiments conducted outside of Oregon have not found that ambient (Corn 1998; P.S. Corn, unpublished data) or simulated ambient UV-B (Little et al. 2003) increased mortality of toad embryos or larvae. The lack of a relationship between UV-B and the distribution of B. boreas breeding sites in GLAC and the Pacific Northwest (Palen et al. 2002) suggests that sensitivity to current levels of ambient UV-B may be a local phenomenon or that levels of mortality observed in experiments are unlikely to affect the distribution of populations (e.g., Biek et al. 2002; Vonesh and De la Cruz 2002; Licht 2003). For example, frequent mortality of $\boldsymbol{B}$. boreas embryos at two populations in Oregon did not result in the long-term population decline that was expected (Olson 2001). At this point there is insufficient evidence to conclude that current levels of UV-B are a widespread threat to $B$. boreas populations in mountainous areas of the western USA.

There are limits to the conclusions that can be drawn from our study. As with most amphibian species (Licht 2003), dose-response data are not available for $B$. boreas to determine damaging levels of UV-B exposure. Sensitivity to UV$B$ also likely varies among regions and populations. Palen et al. (2002) sampled an elevation range similar to ours in the mountains of Oregon and Washington and used the dissolved organic matter (DOM) concentration of ponds to compare UV-B flux with a level experimentally shown to increase mortality of $B$. boreas embryos (Kiesecker et al. 2001). They concluded that few ponds would receive UV-B intensities associated with embryo mortality. The mean DOC concentration of ponds in our study (B. boreas ponds: $\bar{x}=5.60 \mathrm{mg} \cdot \mathrm{L}^{-1}$, $s=5.24$; all ponds: $\bar{x}=4.76 \mathrm{mg} \cdot \mathrm{L}^{-1}, s=5.39$ ) was greater than the DOM concentrations reported by Palen et al. (2002). If $B$. boreas in GLAC are as tolerant as populations in the Pacific Northwest, then most ponds would provide protection from current levels of UV-B.

Because our data are based on presence or non-detection of embryos or larvae, we cannot eliminate the possibility that populations in ponds that receive more UV-B are at greater risk of extinction. Based on 7 years of extensive surveys throughout GLAC (Corn et al. 2005; B.R. Hossack and P.S. Corn, unpublished data), however, we have no reason to expect such a relationship. We also do not know whether the presence of larvae at a site in any given year results in recruitment to the breeding population. It is possible that most breeding ponds do not contribute to the overall population of an area and that a few ponds protected from UV-B serve as the source for most of the recruitment into the breeding population. However, not only did we fail to find a negative re- lationship between estimated UV-B dose and the presence of larvae in individual ponds, but we also found that highelevation areas, where ponds receive more UV-B, had a greater proportion of ponds occupied by breeding populations. Further, toads in GLAC rarely breed in ponds that are heavily shaded by forest. The negative association between shading and breeding site selection is supported by the recent colonization of previously unoccupied ponds after a series of wildfires (B.R. Hossack and P.S. Corn, unpublished data). If a greater number of breeding sites in an area increases the probability of persistence (e.g., Sjögren Gulve 1994), then $B$. boreas may currently be at greater risk in low-elevation areas of the park.

\section{Acknowledgments}

This project was part of a multi-agency collaboration funded by the US Environmental Protection Agency's Parks Research and Intensive Monitoring of Ecosystems Network program and the US Department of the Interior's Amphibian Research and Monitoring Initiative. This document has been subjected to review by the US Environmental Protection Agency's National Health and Environmental Effects Research Laboratory and approved for publication. Approval does not signify that the contents reflect the views of the Agency, nor does mention of trade names or commercial products constitute an endorsement or recommendation for use. We thank M. Adams, C. Pearl, P. Trenham, B. Williams, and two anonymous reviewers for comments that improved the manuscript, and the US Geological Survey and National Park Service staff in Glacier National Park for support throughout the project.

\section{References}

Adams, M.J., Bury, R.B., and Swarts, S.A. 1998. Amphibians of the Fort Lewis Military Reservation, Washington: sampling techniques and community patterns. Northwest Nat. 79: 12-18.

Adams, M.J., Schindler, D.E., and Bury, R.B. 2001. Association of amphibians with attenuation of ultraviolet-b radiation in montane ponds. Oecologia, 128: 519-525.

Adams, M.J., Hossack, B.R., Knapp, R.A., Corn, P.S., Diamond, S.A., Trenham, P.C., and Fagre, D.B. 2005. Distribution patterns of lentic-breeding amphibians in relation to ultraviolet radiation exposure in western North America. Ecosystems, 8: 488-500.

Banks, B., and Beebee, T.J.C. 1987. Factors influencing breeding site choice by the pioneering amphibian Bufo calamita. Holarct. Ecol. 10: 14-21.

Biek, R., Funk, W.C., Maxell, B.A., and Mills, L.S. 2002. What is missing from amphibian decline research: insights from ecological sensitivity analysis. Conserv. Biol. 16: 728-734.

Blaustein, A.R., Hoffman, P.D., Hokit, D.G., Kiesecker, J.M., Walls, S.C., and Hays, J.B. 1994. UV repair and resistance to solar UV-B in amphibian eggs: a link to population declines? Proc. Natl. Acad. Sci. U.S.A. 91: 1791-1795.

Blaustein, A.R., Kiesecker, J.M., Chivers, D.P., Hokit, D.G., Marco, A., Belden, L.K., and Hatch, A. 1998. Effects of ultraviolet radiation on amphibians: field experiments. Am. Zool. 38: 799-812.

Blumthaler, M., Ambach, W., and Rehwald, W. 1992. Solar UV-A and UV-B radiation fluxes at two alpine stations at different altitudes. Theor. Appl. Climatol. 46: 39-44. 
Brooks, P.D., O'Reilly, C.M., Diamond, S.A., Campbell, D.H., Knapp, R.A., Bradford, D., Corn, P.S., Hossack, B.R., and Tonnessen, K. 2005. Spatial and temporal variability in the amount and source of dissolved organic carbon: implications for UV exposure in amphibian habitats. Ecosystems, 8: 478-487.

Burnham, K.P., and Anderson, D.R. 2002. Model selection and multi-model inference: a practical information-theoretic approach. Springer, New York.

Butler, D.R., and DeChano, L.M. 2001. Environmental change in Glacier National Park, Montana: an assessment through repeat photography from fire lookouts. Phys. Geogr. 22: 291-304.

Carrara, P.E. 1989. Late quaternary glacial and vegetative history of the Glacier National Park region, Montana. U.S. Geological Survey Bulletin 1902, Denver, Colo.

Corn, P.S. 1998. Effects of ultraviolet radiation on boreal toads in Colorado. Ecol. Appl. 8: 18-26.

Corn, P.S. 2003. Amphibian breeding and climate change: importance of snow in the mountains. Conserv. Biol. 17: 622-625.

Corn, P.S., and Muths, E. 2002. Variable breeding phenology affects the exposure of amphibian embryos to ultraviolet radiation. Ecology, 83: 2958-2963.

Corn, P.S., Hossack, B.R., Muths, E., Patla, D., Peterson, C.R., and Gallant, A.L. 2005. Status of amphibians on the Continental Divide: surveys on a transect from Montana to Colorado. Alytes, 22: 85-94.

Cummins, C.P. 2003. UV-B radiation, climate change and frogs the importance of phenology. Ann. Zool. Fenn. 40: 61-67.

Diamond, S.A., Peterson, G.S., Tietge, J.E., and Ankley, G.T. 2002. Assessment of the risk of solar ultraviolet radiation to amphibians. III. Prediction of impacts in selected northern midwestern wetlands. Environ. Sci. Technol. 36: 2866-2874.

Diamond, S.A., Trenham, P.C., Adams, M.J., Hossack, B.R., Knapp, R.A., Stark, S.L., Bradford, D., Corn, P.S., Czarnowski, K., Brooks, P.D., Fagre, D., Breen, B., Detenbeck, N.E., and Tonnessen, K. 2005. Estimated ultraviolet radiation doses in wetlands in six national parks. Ecosystems, 8: 462-477.

Fisher, R.N., and Shaffer, H.B. 1996. The decline of amphibians in California's Great Central Valley. Conserv. Biol. 10: 1387-1397.

Green, A.E.S., and Shippnick, P.F. 1982. UV-B reaching the surface. In The role of solar ultraviolet radiation in marine ecosystems. Edited by J. Calkins. Plenum Press, New York. pp. 5-28.

Halverson, M.A., Skelly, D.K., Kiesecker, J.M., and Freidenburg, L.K. 2003. Forest mediated light regime linked to amphibian distribution and performance. Oecologia, 134: 360364.

Hammerson, G.A. 1999. Amphibians and reptiles in Colorado. 2nd ed. University Press of Colorado and Colorado Division of Wildlife, Niwot, Colo.

Herman, J.R., Bhartia, P.K., Ziemke, J., Ahmad, Z., and Larko, D. 1996. UV-B increases (1979-1992) from decreases in total ozone. Geophys. Res. Lett. 23: 2117-2120.

Herman, J.R., Krotkov, N., Celarier, E., Larko, D., and Labow, G. 1999. Distribution of UV radiation at the Earth's surface from TOMS-measured UV-backscattered radiances. J. Geophys. Res. Atmos. 104: 12059-12076.

Institute for Computational Earth System Science. 2006. SBDART: a practical tool for plane-parallel radiative transfer in the Earth's atmosphere [online]. Available from http://www.crseo.ucsb. edu/esrg/pauls_dir/ [cited 5 August 2005].

Jerlov, N.G. 1976. Marine optics. Elsevier Oceanography Series 14. Elsevier, Amsterdam.

Jerome, J.H., and Bukata, R.P. 1998. Tracking the propagation of solar ultraviolet radiation: dispersal of ultraviolet photons in inland waters. J. Gt. Lakes Res. 24: 666-690.
Kagarise Sherman, C., and Morton, M.L. 1993. Population declines of Yosemite toads in the eastern Sierra Nevada of California. J. Herpetol. 27: 186-198.

Kerr, J.B., and McElroy, C.T. 1993. Evidence for large upward trends of ultraviolet-B radiation linked to ozone depletion. Science (Washington, D.C.), 262: 1032-1034.

Kiesecker, J.M., and Blaustein, A.R. 1995. Synergism between UV-B radiation and a pathogen magnifies amphibian embryo mortality in nature. Proc. Natl. Acad. Sci. U.S.A. 92: 1104911052.

Kiesecker, J.M., Blaustein, A.R., and Belden, L.K. 2001. Complex causes of amphibian population declines. Nature (London), 410: 681-684.

Klasner, F.L., and Fagre, D.B. 2002. A half century of change in alpine treeline patterns at Glacier National Park, Montana, U.S.A. Arct. Antarct. Alp. Res. 34: 49-56.

Licht, L.E. 2003. Shedding light on ultraviolet radiation and amphibian embryos. Bioscience, 53: 551-561.

Little, E.E., Calfee, R.D., Fabacher, D.L., Carey, C., Blazer, V.S., and Middleton, E.M. 2003. Effects of ultraviolet radiation on toad early life stages. Environ. Sci. Pollut. Res. Int. 10: 167172.

Maxell, B.A., Werner, J.K., Hendricks, P., and Flath, D.L. 2003. Herpetology in Montana. Northwest Fauna, 5: 1-135.

McKnight, D., Harnish, M.R., Wershaw, R.L., Baron, J.S., and Schiff, S. 1997. Chemical characteristics of particulate, colloidal, and dissolved organic material in Loch Vale watershed, Rocky Mountain National Park. Biogeochemistry, 36: 99-124.

Merilä, J., Pahkala, M., and Johansson, U. 2000. Increased ultraviolet-B radiation, climate change and latitudinal adaptation - a frog perspective. Ann. Zool. Fenn. 37: 129-134.

Middleton, E.M., Herman, J.R., Celarier, E.A., Wilkinson, J.W., Carey, C., and Rusin, R.J. 2001. Evaluating ultraviolet radiation exposures with satellite data at sites of amphibian declines in Central and South America. Conserv. Biol. 15: 914-929.

Muths, E., Corn, P.S., Pessier, A.P., and Green, D.E. 2003. Evidence for disease-related amphibian decline in Colorado. Biol. Conserv. 110: $357-365$

National Aeronautics and Space Administration. 2005. Total Ozone Mapping Spectrometer [online]. Available from http:// jwocky. gsfc.nasa.gov/index.html [cited 8 August 2005].

Natural Resources Conservation Service. 2005. National Water and Climate Center [online]. Available from http://www.wcc.nrcs. usda.gov [cited 8 August 2005].

O'Hara, R.K., and Blaustein, A.R. 1982. Kin preference behavior in Bufo boreas tadpoles. Behav. Ecol. Sociobiol. 11: 43-49.

Olson, D.H. 2001. Ecology and management of montane amphibians of the U.S. Pacific Northwest. Biota, 2: 51-74.

Palen, W.J., Schindler, D.E., Adams, M.J., Pearl, C.A., Bury, R.B., and Diamond, S.A. 2002. Optical characteristics of natural waters protect amphibians from UV-B in the Pacific Northwest. Ecology, 83: 2951-2957.

Palen, W.J., Williamson, C.E., Clauser, A.A., and Schindler, D.E. 2005. Impact of UV-B exposure on amphibian embryos: linking species physiology and oviposition behaviour. Proc. R. Soc. Lond. B Biol. Sci. 272: 1227-1234.

Pederson, G.T., Gray, S.T., Fagre, D.B., and Graumlich, L.J. 2006. Long-duration drought variability and impacts on ecosystem services: a case study from Glacier National Park, USA. Earth Interact. In press.

Ricchiazzi, P., Yang, S., Gautier, C., and Sowle, D. 1998. SBDART: a research and teaching software tool for planeparallel radiative transfer in the Earth's atmosphere. Bull. Am. Meteorol. Soc. 79: 2101-2114. 
Rich, P.M., Hetrick, W.A., and Saving, S.C. 1995. Modeling topographic influences on solar radiation: a manual for the solarflux model. Los Alamos National Laboratory, Los Alamos, N. Mex.

Schindler, D.W., and Curtis, P.J. 1997. The role of DOC in protecting freshwaters subjected to climatic warming and acidification from UV exposure. Biogeochemistry, 36: 1-8.

Scully, N.M., and Lean, D.R.S. 1994. The attenuation of ultraviolet radiation in temperate lakes. Arch. Hydrobiol. 43: 135-144.

Selkowitz, D.J., Fagre, D.B., and Reardon, B.A. 2002. Interannual variations in snowpack in the Crown of the Continent Ecosystem. Hydrol. Process. 16: 3651-3665.

Sjögren Gulve, P. 1994. Distribution and extinction patterns within a northern metapopulation of the pool frog, Rana lessonae. Ecology, 75: 1357-1367.

Skelly, D.K., Freidenburg, L.K., and Kiesecker, J.M. 2002. Forest canopy and the performance of larval amphibians. Ecology, 83: 983-992.
Steedman, R.J., Kushneriuk, R.S., and France, R.L. 2001. Littoral water temperature response to experimental shoreline logging around small boreal forest lakes. Can. J. Fish. Aquat. Sci. 58: 1638-1647.

Vonesh, J.R., and De la Cruz, O. 2002. Complex life cycles and density dependence: assessing the contribution of egg mortality to amphibian declines. Oecologia, 133: 325-333.

Vredenburg, V.T. 2002. The effects of introduced trout and ultraviolet radiation on anurans in the Sierra Nevada. Ph.D. thesis, University of California, Berkeley, Calif.

Werner, E.E., and Glennenmeier, K.S. 1999. Influence of forest canopy cover on the breeding pond distributions of several amphibian species. Copeia, 1999: 1-12.

Williamson, C.E., Olson, O.G., Lott, S.E., Walker, N.D., Engstrom, D.R., and Hargreaves, B.R. 2001. Ultraviolet radiation and zooplankton community structure following deglaciation in Glacier Bay, Alaska. Ecology, 82: 1748-1760. 